\title{
Sciendo
}

\section{Left Ventricular noncompaction in a patient with systemic lupus erythematosus}

\author{
MIHAELA DOBRANICI ${ }^{1,2}$, ANAMARIA TOCITU ${ }^{3}$, CATERINA DELCEA ${ }^{1,2,4}$, \\ GHEORGHE-ANDREI DAN ${ }^{1,2}$ \\ 1“"Carol Davila" University of Medicine and Pharmacy, Bucharest, Romania \\ ${ }^{2}$ Cardiology Department, "Colentina” Clinical Hospital, Bucharest, Romania \\ ${ }^{3}$ Internal Medicine Department, "Colentina" Clinical Hospital, Bucharest, Romania \\ ${ }^{4}$ CDPC Cardiology Laboratory, "Colentina” Clinical Hospital, Bucharest, Romania
}

\begin{abstract}
Left ventricular noncompaction is a rare structural cardiomyopathy that can occur isolated or in relationship with other conditions, mainly with musculoskeletal diseases or congenital heart defects. The association of left ventricular noncompaction and connective tissue disorders, including systemic lupus erythematosus, was scarcely described in the literature. Reported cases are, more likely, cardiomyopathies mimicking left ventricular noncompaction or transient left ventricular noncompaction with ventricular function improving after appropriate treatment.

We present the case of a 23-year-old woman admitted for cardiac evaluation because of ECG abnormalities observed during a routine check-up. Echocardiography showed severe systolic and diastolic dysfunction, diffuse hypokinesis and hypertrabeculation, suggestive of left ventricular noncompaction. Cardiac magnetic resonance imaging confirmed the diagnosis. She later presented with specific clinical and biological parameters and was diagnosed with systemic lupus erythematosus. Corticosteroid and hydroxychloroquine treatment induced general improvement of signs and symptoms, but no recovery of cardiac function.
\end{abstract}

Keywords: left ventricular noncompaction, LVNC, cardiomyopathy, systemic lupus erythematosus.

\section{INTRODUCTION}

Left ventricular noncompaction (LVNC) is a rare structural abnormality of the left ventricular myocardium characterized by a spongy endocardial layer and a compacted epicardial layer [1]. The European Society of Cardiology Working Group on Myocardial and Pericardial Diseases categorized LVNC as either a familial unclassified cardiomyopathy or a morphological feature of many phenoltypically distinct cardiomyopathies [2]. Clinical heterogeneity ranges from asymptomatic to severe or life-threatening manifestations such as heart failure, ventricular arrhythmias or systemic thromboembolism [3]. The diagnosis is based on imaging: echocardiography and magnetic resonance (MRi). However, the existing diagnostic criteria have significant limitations which can result in overdiagnosis $[4,5]$.

LVNC can occur either isolated, or associated with neuromuscular disorders or congenital heart defects [1]. Case reports describing the link between left ventricular noncompaction and systemic lupus erythematosus (SLE) conclude with the diagnosis of transient LVNC [6] or myocarditis [7].

Herein, we report probably the first case of a patient with SLE and LVNC.

\section{CLINICAL CASE}

A 23-year-old Caucasian female presented to our Cardiology Department referred by her primary care physician for an abnormal electrocardiogram (ECG) and cardiomegaly on the chest x-ray. ECG (Figure 1) showed poor $\mathrm{R}$ wave progression in leads V1-V3 and negative T waves in leads DI, DII, aVF, V4-V6. She was asymptomatic on admission. Personal and family medical history was negative for heart disease. Physical examination was normal, except for a grade III/VI systolic murmur heard over the apex, radiating to the axilla. Routine blood 
work was normal, except for an increased NT-proBNP of $3000 \mathrm{pg} / \mathrm{mL}$ (normal range $0-125 \mathrm{pg} / \mathrm{mL}$ ).

Echocardiography (Figure 2) showed left ventricular (LV) enlargement, severe systolic dysfunction with a LV ejection fraction of $25 \%$, restrictive diastolic dysfunction and diffuse LV hypokinesia. LV apical and lateral wall trabeculations were detected, suggestive of left ventricular noncompaction (LVNC). Our patient met all the Stöllberger et al. refined echocardiographic diagnostic criteria (Table 1) [8].
Cardiac MRi established the diagnosis, confirming LV trabecular mass more than $20 \%$ of the global LV mass and an increased ratio between the noncompacting and compacting myocardium $>$ 2.3 in end-diastole (Figure 3). Holter monitoring revealed multiple episodes of unsustained ventricular tachycardia.

Treatment with ramipril, bisoprolol, and spironolactone was initiated, as well as acenocumarol titrated doses for a therapeutical INR. She received an implanted cardiac defibrillator for primary prevention of sudden cardiac death.

Table 1

Stöllberger et al. refined echocardiographic criteria for diagnosis of LVNC [8]

\begin{tabular}{l}
$\begin{array}{c}>3 \text { prominent trabeculous formations along the left ventricular endocardial border visible in end-diastole, distinct from papillary } \\
\text { muscles, false tendons or aberrant bands }\end{array}$ \\
\hline Trabeculations move synchronously with the compacted myocardium \\
\hline Trabeculations form the noncompacted part of a two-layered myocardial structure, best visible at end-systole \\
\hline $\begin{array}{c}\text { Perfusion of the intertrabecular spaces from the ventricular cavity is present at end-diastole on color-Doppler echocardiography or } \\
\text { contrast echocardiography. }\end{array}$ \\
\hline
\end{tabular}

*All 4 criteria should be fulfilled for the diagnosis of LVNC

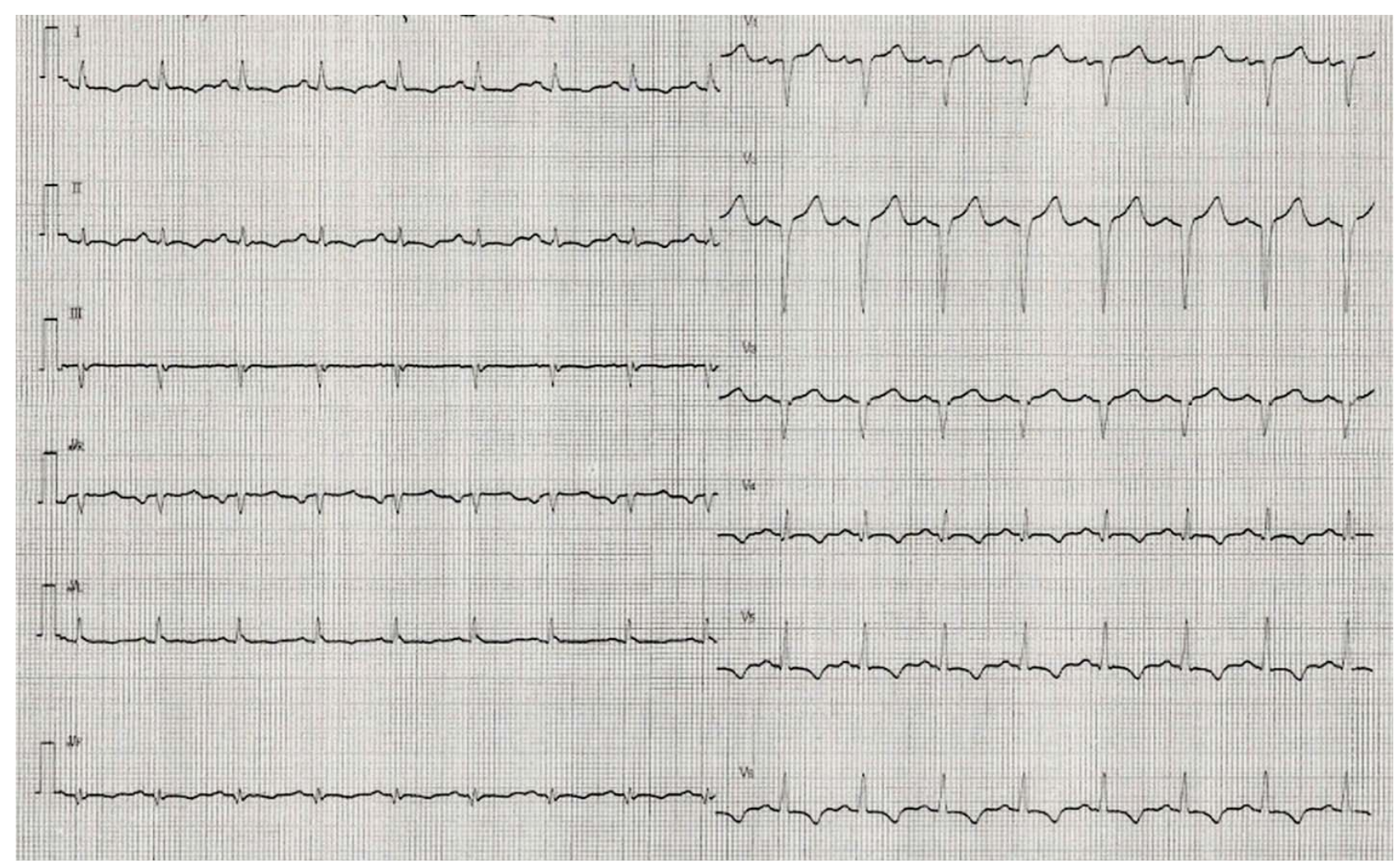

Figure 1. Electrocardiogram showing poor R wave progression in V1-V3 leads and negative $\mathrm{T}$ waves in DI, DII, aVF, V4-V6 leads. 


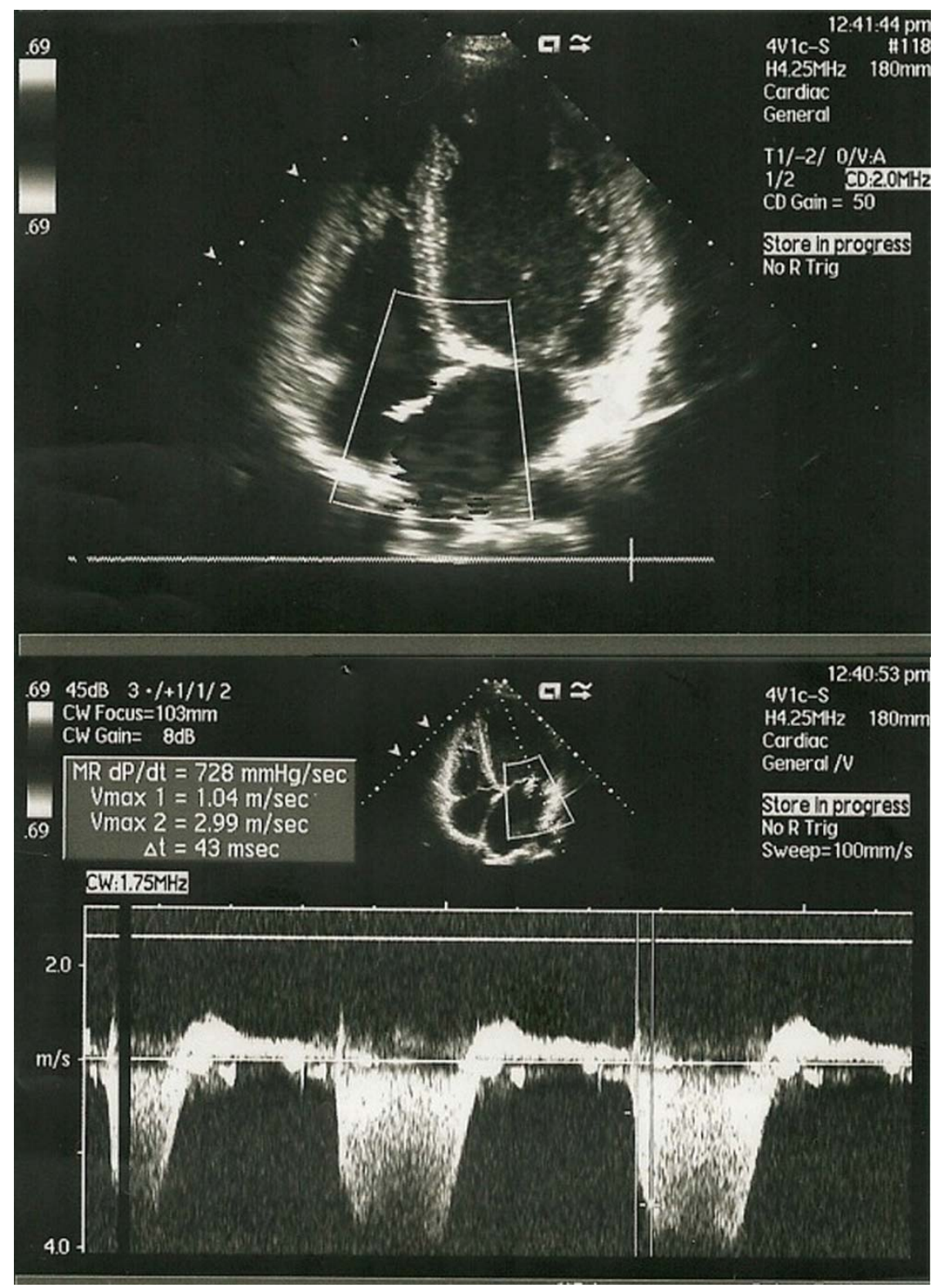

Figure 2. Echocardiogram showing left ventricular apical and lateral wall trabeculations and the associated filling pattern.

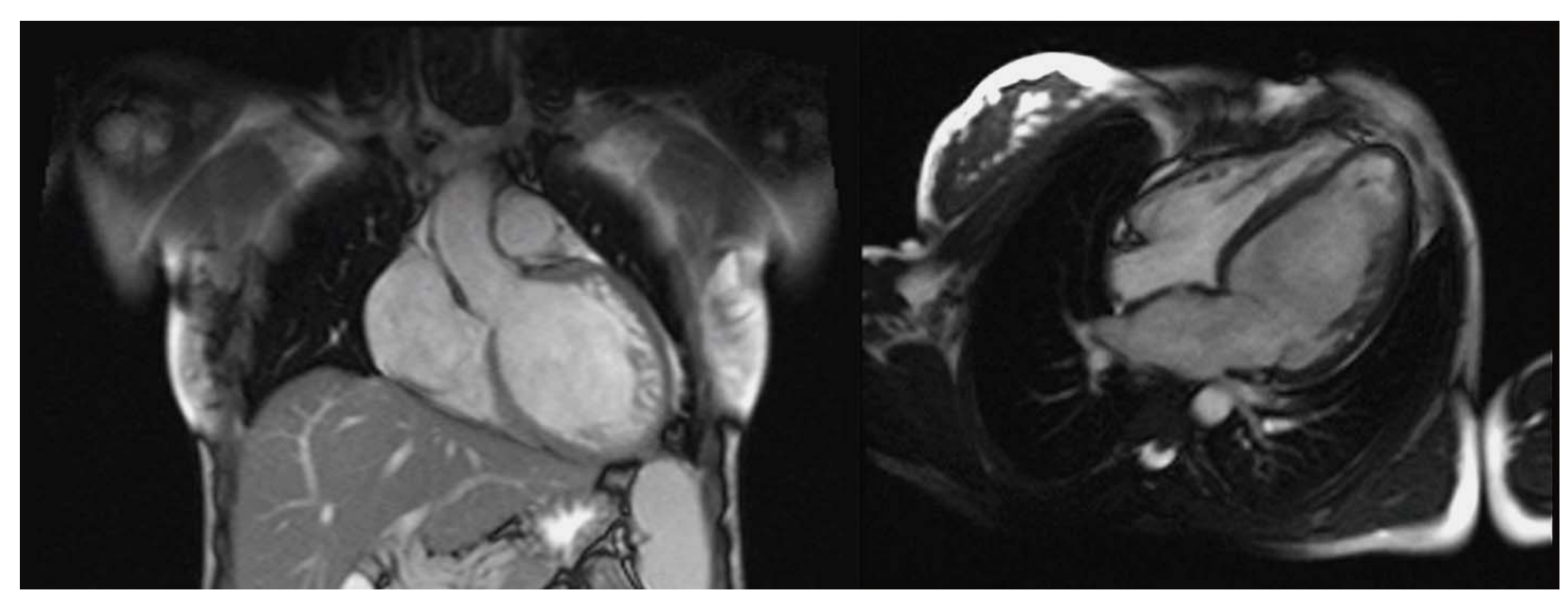

Figure 3. Cardiac MR imaging showing left ventricular trabeculations (frontal and sagittal view). 
After a few months, the patient was readmitted to the Internal Medicine Department for fever, weight loss and generalized lymph node enlargement. Clinical examination revealed livedo reticularis of the lower limbs, pale skin and mucosal membranes, non-scarring alopecia, generalized enlarged, mobile, painless lymph nodes, and hepatosplenomegaly. Cardiac auscultation was unchanged. Laboratory tests showed hemolytic anemia, lymphopenia, low complement levels, a high ANA titer, and positive anti-DNA and anti-Sm antibodies. She was diagnosed with systemic lupus erythematosus and received methylprednisolone pulse-therapy. Oral corticosteroid and hydroxychloroquine therapy was then started with significant clinical and biological improvement, except for the cardiac condition. ECG and echocardiographic aspects remained unchanged. Heart failure medication was revised and optimized, and the ICD was upgraded to resynchronization therapy with implanted cardiac defibrillator.

Five years later she was readmitted for decompensated heart failure. The echocardiogram showed persistent LV hypertrabeculation and worsened LV systolic dysfunction with a severely decreased LVEF of $15 \%$. Clinical and biological decline occurred despite optimal medical and device therapy. The patient was then referred to a specialized heart transplant center.

\section{DISCUSSION}

Cardiac involvement is not uncommon in SLE. Pericarditis, myocarditis, nonbacterial endocarditis, coronary artery disease, premature coronary atherosclerosis or congestive heart failure are known to occur in SLE [9]. However, a cardiac manifestation in the form of a cardiomyopathy mimicking LVNC was rarely described in these patients $[6,7,10]$. In previously reported cases the proposed imaging criteria for LVNC were present, however the final diagnosis was cardiomyopathy resembling noncompaction [6, 7] or myocarditis with noncompaction features [10]. These reports also share a pattern of reversibility, with cardiac function improving after aggressive SLE treatment $[6,7$, 10]. In the case we presented, all the Stöllberger and Finesterer [5] echocardiographic criteria were met, and LVNC diagnosis was confirmed by cardiac MRi. Our patient's systolic function had a continuous decline with no improvement after treating SLE. Furthermore, the initial diagnosis of LVNC was established before the patient presented the first SLE flair. In other cases, the aspect of LVNC was described as part of SLE activity or after initial SLE diagnosis [6, 7]. Considering all the available data, we consider LVNC as the most accurate diagnosis in our case, independent of SLE manifestations.

There is limited evidence regarding therapeutic efficacy in LVNC. Treatment involves three main objectives: heart failure therapy, antiarrhythmic therapy and antithrombotic therapy [11]. Our patient received the recommended heart failure treatment according to the European Society of Cardiology Heart Failure Guidelines [12]. Anticoagulation therapy is still a matter of debate in LVNC. In the case presented here anticoagulation was decided mainly because of the impaired systolic function. Oechslin and Jenni [13] indicated that prevention of embolic events should be considered if left ventricle ejection fraction is under $40 \%$, since reduction of the blood flow can predispose to thrombus formation in the intertrabecular recesses. In some LVNC cases, the $\mathrm{CHA}_{2} \mathrm{DS}_{2}$-Vasc score can be a useful decision tool in establishing the indication of oral anticoagulation [14]. Primary prevention of sudden cardiac death is another critical issue in patients with LVNC. In our case an internal cardiac defibrillator was implanted after documenting a severely reduced LV ejection fraction. In LVNC patients implantation of a cardiac defibrillator should be considered following the guidelines for primary and secondary prevention of sudden cardiac death [1].

In summary, we report one of the rare documented cases of SLE associated with "real" LVNC. Differentiating LVNC from other cardiomyopathies can be challenging, especially when it is part of a wider context such as a connective tissue disorder. The imaging diagnostic criteria are always useful, however the key to the diagnosis is to integrate each patient's characteristics into its unique clinical context.

Conflict of interest. The authors have no potential conflicts of interest with respect to the research, authorship, and/or publication of this article.

Funding. The authors received no financial support for the research, authorship, and/or publication of this article.

Noncompactarea de ventricul stâng este o cardiomiopatie structurală ce poate apărea izolată sau în asociere cu alte afecțiuni, în principal cu boli musculoscheletale sau boli cardiace congenitale. Asocierea dintre noncompactarea de 
ventricul stâng şi bolile țesutului conjunctiv, inclusiv lupusul eritematos sistemic, a fost rar descrisă în literatură. Cazurile clinice raportate sunt adesea cardiomiopatii ce simulează noncompactarea de ventricul stâng sau sunt noncompactări ventriculare stângi tranzitorii, funcția ventriculară îmbunătățindu-se după tratamentul adecvat.

Prezentăm cazul unei paciente în vârstă de 23 de ani, internată pentru evaluare cardiologică în contextul unor modificări ECG observate în cadrul unui consult de rutină. Ecocardiografia a identificat disfuncție ventriculară sistolică şi diastolică severă, hipokinezie difuză şi hipertrabeculare, modificări sugestive pentru noncompactarea de ventricul stâng. Imagistica prin rezonanță magnetică a confirmat diagnosticul. Ulterior, în context clinic şi biologic specific, a fost diagnosticată cu lupus eritematos sistemic. Tratamentul corticosteroidian şi cu hidroxiclorochină a indus ameliorarea semnelor şi simptomelor, însă nu şi recuperarea funcției cardiace.

Correspondence to: Anamaria Tocitu, MD, Internal Medicine Department, "Colentina” Clinical Hospital, Sos Stefan cel Mare, Nr 19-21, Pavilion E, Sector 2, Bucharest, Romania E-mail: anamaria_tocitu@yahoo.com

\section{REFERENCES}

1. FINSTERER J, STÖLLBERGER C, TOWBIN JA. Left ventricular noncompaction cardiomyopathy: cardiac, neuromuscular and genetic factors. Nat Rev Cardiol 2017;14:224-37.

2. ELLIOTT P, ANDERSSON B, ARBUSTINI E, BILINSKA Z, CECCHI F, CHARRON P, et al. Classification of the cardiomyopathies: a position statement from the European society of cardiology working group on myocardial and pericardial diseases. Eur Heart J 2008;29:270-6.

3. HUSSEIN A, KARIMIANPOUR A, COLLIER P, KRASUSKI RA. Isolated Noncompaction of the Left Ventricle in Adults. J Am Coll Cardiol 2015;66:578-85.

4. JENNI R, OECHSLIN E, SCHNEIDER J, ATTENHOFER JOST C, KAUFMANN PA. Echocardiographic and pathoanatomical characteristics of isolated left ventricular non-compaction: a step towards classification as a distinct cardiomyopathy. Heart 2001;86:666-71.

5. STÖLLBERGER C, FINSTERER J. Left ventricular hypertrabeculation/noncompaction. J Am Soc Echocardiogr 2004;17:91-100.

6. RABELO CF, BATISTELLA F, GODINHO RN, MACHADO TS, VELHO FJP, STAUB HL. Systemic lupus erythematosus and transient left ventricular noncompaction. Acta Reumatol Port 2014;39:274-6.

7. OZKOK A, ACAR G, ELCIOGLU OC, BAKAN A, ATILGAN KG, SASAK G, et al. Cardiomyopathy mimicking left ventricular noncompaction in a patient with lupus nephritis. CEN Case Reports 2012;1:69-72.

8. STÖLLBERGER C, GERECKE B, FINSTERER J, ENGBERDING R. Refinement of echocardiographic criteria for left ventricular noncompaction. Int J Cardiol 2013;165:463-7.

9. LIN K, LLOYD-JONES DM, LI D, LIU Y, YANG J, MARKL M, et al. Imaging of cardiovascular complications in patients with systemic lupus erythematosus. Lupus 2015;24:1126-34.

10. ASHRAFI R, GARG P, MCKAY E, GOSNEY J, CHUAH S, DAVIS G. Aggressive cardiac involvement in systemic lupus erythematosus: a case report and a comprehensive literature review. Cardiol Res Pract 2011;2011:578390.

11. TOWBIN JA, JEFFERIES JL. Cardiomyopathies Due to Left Ventricular Noncompaction, Mitochondrial and Storage Diseases, and Inborn Errors of Metabolism. Circ Res 2017;121:838-54.

12. PONIKOWSKI P, VOORS AA, ANKER SD, BUENO H, CLELAND JGF, COATS AJS, et al. 2016 ESC Guidelines for the diagnosis and treatment of acute and chronic heart failure. Eur Heart J 2016;37:2129-200.

13. OECHSLIN E, JENNI R. Left ventricular non-compaction revisited: a distinct phenotype with genetic heterogeneity? Eur Heart J 2011;32:1446-56.

14. BENNETT CE, FREUDENBERGER R. The Current Approach to Diagnosis and Management of Left Ventricular Noncompaction Cardiomyopathy: Review of the Literature. Cardiol Res Pract 2016;2016:1-7.

Received October 11, 2018 